\title{
ANALISIS FAKTOR-FAKTOR DALAM PEMBANGUNAN DI DESA SEI PUTIH KECAMATAN TAPUNG KABUPATEN KAMPAR
}

\author{
Rafida Ulfa $^{1}$, Wan Asrida ${ }^{2}$, Raja Muhammad Amin ${ }^{3}$, Baskoro Wicaksono ${ }^{4}$ \\ 1,2,3,4 Jurusan Ilmu Pemerintahan, Fakultas Ilmu Sosial Dan Ilmu Politik, Universitas Riau \\ Pekanbaru, Indonesia \\ wicaksonobaskoro@gmail.com
}

\begin{abstract}
ABSTRAK
Penelitian ini dilatarbelakangi pembangunan yang terjadi di desa sei putih Kecamatan Tapung, Kabupaten Kampar yang berjalan kurang efektif sesuai dengan musrenbang desa yang telah dibuat oleh Pemerintah Desa. Beberapa pembangunan yang direalisasikan tidak tercapai penyelesaian pembangunan sepenuhnya sehingga bangunan yang dibuat belum bisa digunakan oleh masyarakat. Penelitian ini akan membahas factor-faktor yang menghambat dalam pembangunan di desa sei baru dan menganalisis factor-faktor tersebut dilihat dari isi kebijakan dan lingkungan kebijakan.Jenis yang digunakan dalam penelitian ini adalah jenis penelitian deskriptif dengan pendekatan penelitian kualitatif. Jenis data penelitian adalah data primer dan data sekunder sesuai dengan regulasi . Teknik pengumpulan data dalam penelitian ini adalah dokumentasi dan wawancara. Teknis analisis data yang digunakan adalah analisis data deskriptif kualitatif.

Hasil penelitian ini menunjukkan bahwa factor-faktor yang menpengaruhi dalam pembangunan di desa sei putih kecamatan tapung kabupaten Kampar dilihat dari indikator isi kebijakan dan lingkungan kebijakan menjelaskan bahwa pelaksanaan pembangunan masih belum optimal. Hal ini dikarenakan kepentingan-kepentingan yang mempengaruhi dalam pelaksanaan pembangunan yang tidak konsisten dan pengambil keputusan dari tingkat pimpinan dalam hal ini kepala desa yang belum mampu mengelola keuangan desa dengan baik dalam pembangunan dan pelaksana program yang tidak professional sehingga terjadi keterlambatan. Sedangkan melalui lingkungan kebijakan daya patuh masyrakat yang masih belum optimal di desa sei putih.
\end{abstract}

\section{Kata Kunci: Kebijakan, Pelaksanaan, dan Pembangunan Desa}

\section{PENDAHULUAN}

Undang Undang Nomor 6 Tahun 2014, Pasal 78 ayat 1, Pembangunan desa bertujuan meningkatkan kesejahteraan masyarakat desa dan kualitas hidup manusia serta penanggulangan kemiskinan melalui pemenuhan kebutuhan dasar, pembangunan sarana dan prasarana desa, pengembangan potensi ekonomi lokal, serta pemanfaatan sumber daya alam dan lingkungan

secara

berkelanjutan.Kesejahteraan Masyarakat Desa akan terjadi jika Pembangunan dapat terlaksana dengan baik. Keberhasilan Pembangunan tersebut tidak luput dari adanya dukungan dan partisipasi masyarakat, dalam hal ini dapat dikatakan bahwa masyarakatlah yang memiliki posisi paling penting dalam proses pembangunan. Misalnya dalam pemberian usulan 
NAKHODA:

JURNAL

ILMU PEMERINTAHAN
NAKHODA: JURNAL ILMU PEMERINTAHAN

Edisi Januari - Juni 2019 Volume: 18 Nomor: 31

ISSN : 1829-5827 |E-ISSN : 2656-5277

DOI : https://doi.org/10.35967/jipn

https://nakhoda.ejournal.unri.ac.id/index.php/JIPN pembangunan, perencanaan pembangunan, perawatan pembangunan, penjagaan hasil pembangunan dan evaluasi pembangunan.

Melaksanakan pembangunan desa bersumber dana dari dana desa dalam APBN setiap tahun anggaran yang diperuntukkan bagi Desa yang ditransfer melalui APBN Kabupaten/Kota mengalokasikan dalam APBD Kabupaten/Kota ADD setiap tahun anggaran, paling sedikit 10 persen dari dana perimbangan yang diterima Kabupaten/Kota dalam APBD setelah dikurangi dana alokasi khusus (ADK).Anggaran pembangunan yang ada di Desa Sei Puth meliputi Dana Desa (DD) dalam anggaran Pendapatan dan Belanja Negara (APBN), Anggaran Pendapatan dan Belanja Daerah (APBD) yang berbentuk Pendapatan Asli Daerah (PAD) yang meliputi Pajak Daerah,
Retribusi daerah dan hasil kekayaan daerah. Serta Anggaran Pendapatan dan Pendapatan dan Belanja Desa (APBDes) yang berbentuk Alokasi Dana Desa (ADD).

Dana Desa diatas digunakan untuk pembangunan di desa sei putih sesuai dengan musrenbang desa yang telah di buat oleh pemerintah Desa Sei Putih Kecamatan Tapung Kabupaten Kampar. Pembangunan dikatakan berhasil jika membawa perubahan kesejahteraan di masyarakat sehingga proses pembangunan merupakan proses tawar menawar antara keutuhan masyarakat dengan keinginan pemerintah, terlihat dalam proses peerencanaan pembangunan yang dikenal dengan istilah Musyawarah Perencanaan Pembangunan (Musrenbang). Adapun realisasi pembangunan di desa sei putih antara

Tabel 1Realisasi Pembangunan di Desa Sei Putih Tahun 2016

\begin{tabular}{|c|c|c|c|c|}
\hline No & Program/Kegiatan & Dana (Rp) & Realisasi (Rp) & $\begin{array}{l}\text { Persentase } \\
\quad(\%)\end{array}$ \\
\hline 1 & 2 & 3 & 4 & 5 \\
\hline I & Pembangunan Gedung Tpa & Rp. 145.000 .000 & Rp. 58.000.000 & $40 \%$ \\
\hline 2 & $\begin{array}{l}\text { Pembangunan Gedung MDA } \\
\text { Nurul Iman }\end{array}$ & Rp. 150.000 .000 & $\mathrm{Rp}-$. & $0 \%$ \\
\hline 3 & $\begin{array}{l}\text { Pembangunan Masjid Dan } \\
\text { Mushalla }\end{array}$ & Rp. 125.000 .000 & Rp. 93.750 .000 & $75 \%$ \\
\hline 4 & Pembangunan Los Pasar Desa & Rp. 8.283.000.000 & Rp. 8.283.000.000 & $100 \%$ \\
\hline 5 & Bantuan Ternak Sapi & Rp. 9.200.000.000 & Rp. -. & $0 \%$ \\
\hline 6 & Rumah Layak Huni & Rp. 7.367.000.000 & Rp. -. & $0 \%$ \\
\hline 7 & Pembangunan Gedung Paud & Rp. 256.000.000 & Rp. 256.000.000 & $100 \%$ \\
\hline 8 & Pembangunan Gedung Sma & Rp. 404.000 .000 & Rp. 224.624.000 & $55,6 \%$ \\
\hline 9 & $\begin{array}{l}\text { Pembangunan Gedung Puskesdes } \\
\text { Pembantu }\end{array}$ & Rp. 150.000 .000 & Rp. 96.000 .000 & $64 \%$ \\
\hline 10 & $\begin{array}{l}\text { Pengaspalan Jalan Poros Teratai } \\
\text { 1,6 Dan } 7\end{array}$ & Rp. 1.375.000.000 & Rp. 797.500.000 & $58 \%$ \\
\hline 11 & $\begin{array}{l}\text { Pengerasan Jalan Lingkungan } \\
\text { Desa Teratai 2,3 Dan } 5\end{array}$ & Rp. 1.700.000.000 & Rp. 1.666.000.000 & $98 \%$ \\
\hline 12 & Pembangunan Pagar Kantor Desa & Rp. 1.250 .000 .000 & Rp. 1.250.000.000 & $100 \%$ \\
\hline
\end{tabular}


NAKHODA:

JURNAL

ILMU PEMERINTAHAN
NAKHODA: JURNAL ILMU PEMERINTAHAN

Edisi Januari - Juni 2019 Volume: 18 Nomor: 31

ISSN : 1829-5827 |E-ISSN : 2656-5277

DOI : https://doi.org/10.35967/jipn

https://nakhoda.ejournal.unri.ac.id/index.php/JIPN

\begin{tabular}{|c|l|l|l|l|}
\hline 13 & Pembangunan Gapura Desa & Rp. 1.170.000.000 & Rp. 367.000.000 & $34 \%$ \\
\hline \multicolumn{2}{|c|}{ Jumlah } & 31.575 .000 .000 & Rp. 13.091 .874 .000 & $41.46 \%$ \\
\hline
\end{tabular}

Dari tabel diatas bisa dilihat bahwa masih banyak program desa yang belum terealisasi dengan target yang telah direncanakan. Khususnya pembangunan fisik dalam meningkatkan ekonomi rakyat yang merupakan kebutuhan pokok bagi masyarakat, namun dalam kenyataannya belum terealisasi dengan optimal. Rencana Pembangunan Jangka Menengah Desa (RPJM-Desa) dalam periode 2015-2020 sebesar Rp. 31.575.000.000 yang dialokasikan untuk pembangunan di desa. Akan tetapi dana yang terealisasi dalam pembangunan di desa Sei Putih Kecamatan Tapung hanya sebesar Rp. 18.483.126.000. pembangunan yang ada di Desa Sei Putih Kecamatan Tapung Kabupaten Kampar disertai dengan Sumber dana yang diterima Desa Sei Putih untuk keperluan pembangunan Desa. Desa seharusnya bisa mengembangkan diri dan terlepas dari kesulitan dan terhindar dari kemiskinan. Menurut ketentuan umum Pasal 1 ayat 6, Peraturan Menteri Dalam Negeri Nomor 113 tahun 2014 tentang pengelolaan dana desa adalah Pengelolaan keuangan desa adalah keseluruhan kegiatan yang meliputi perencanaan, pelaksanaan, penatausahaan, pelaporan, dan pertanggungjawaban keuangan desa. Program pembangunan yang direalisasikan di desa sei puth kecamatan tapung belum mampu memberikan dampak yang baik masyarakat. Masih terdapat kebutuhan sarana infrastruktur yang masih belum dapat dilakukan. Tentu hal ini perlu dilakukan tinjauan terhadap pembangunan yang akan dilakukan agar optimal dengan mengetahui penyebab pembangunan di desa sei putih. Sehingga dapat di tarik pertanyaan penelitian yaitu : Apa saja faktor-faktor yang mempengaruhi pembangunan di desa sei putih kecamatan tapung kabupaten Kampar tahun 2016?

\section{KERANGKA TEORI \\ Implementasi kebijakan}

Impementasi kebijakan dipandang dalam pengertin luas, merupakan tahap dari proses kebijakan segera setelah penetapan undang-undang. Implementasi dipandang secara luas mempunyai makna pelaksanaan Undang-Undang dimana sebagai actor, organisasi, prosedur, dan teknik bekerja bersama-sama untuk menjalankan kebijakan dalam upaya untuk meraih tujuan-tujuan kebijakan atau program-program. Implementasi pada sisi yang lain merupakan fenomena yang kompleks yang mungkin dapat dipahami sebagai suatu proses, suatu keluaran(output) maupun sebagai suatu dampak(outcome). (Winarno,2012). Menurut Grindle (Nugroho,2004), implementasi sebagai rangkaian antara tujuan kebijakan dan hasil-hasil kegiatan pemerintah, karena itu implementasi kebijakan membutuhkan adanya sistem pelaksanaan kebijakan cara yang diterjemahkan kedalam tindakantindakan program untuk mencapai tujuan akhir seperti yang ditetapkan oleh kebijakan. Grindle menyatakan, implementasi merupakan proses umum tindakan administratif yang dapat diteliti pada tingkat program tertentu. Proses Implementasi baru akan dimulai apabila tujuan dan sasaran telah ditetapkan, 
NAKHODA:

JURNAL

ILMU PEMERINTAHAN
NAKHODA: JURNAL ILMU PEMERINTAHAN

Edisi Januari - Juni 2019 Volume: 18 Nomor: 31

ISSN : 1829-5827 |E-ISSN : 2656-5277

DOI : https://doi.org/10.35967/jipn

https://nakhoda.ejournal.unri.ac.id/index.php/JIPN program kegiatan tersusun dan dana telah siap dan telah disalurkan untuk mencapai sasaran. Implementasi kebijakan menghubungkan antara tujuan kebijakan dan realisasinya dengan hasil kegiatan pemerintah.( Al-ikhlas, 2014)

Grindle juga menyatakan bahwa implementasi pada dasarnya merupakan upaya menerjemahkan kebijakan publik yang merupakan pernyataan luas tentang maksud, tujuan dan cara mencapai tujuan kedalam berbagai program aksi untuk mencapai tujuan tertentu yang telah ditetapkan dalam suatu kebijakan. Dengan demikian, implementasi berhubungan dengan penciptaan "policy delivery sytem" yang menghubungkan tujuan kebijakan dengan output atau outcomes tertentu. Menurut Grindle dalam sujianto mengarahkan implementasi kebijakan bukan sekedar hubungan dengan mekasisme penjabaran atau operasional dari keputusan politik kedalam prosedur-prosedur rutin lewat saluran birokrasi, melainkan lebih dari itu yaitu menyangkut masalah konflik, keputusan, dan siapa memperoleh apa dari suatu kebijakan. (Sujianto,2008)

$$
\text { Grindle dalam sujianto }
$$

mengemukakan bahwa setidaknya ada tiga faktor yang mempengaruhi keberhasilan implementasi,yaitu

1. Kejelasan tujuan-tujuan program dan tingkat consensus diantara pelaksana atas tujuan-tujuan tersebut

2. Tingkat perubahan dari kebiasaankebiasaan lama yang dikehendaki program

3. Tipe-tipe orang yang memperoleh manfaat dan klien terbatas yaitu orang dan kelompok yang menjadi target implementasi

Menurut Gindle bahwa berhasil atau tidaknya sebuah kebijakan tersebut di tentukan oleh dua variable yaitu "content of policy"(isi kebijakan) dan variable “ context of policy"( lingkungan kebijakan). Variable isi kebijakan mencakup yaitu:

1. Sejauh mana kepentingan kelompok sasaran dan target group termuat dalam isi kebijakan

2. Jenis dan manfaat yang diterima oleh target group

3. Sejauh mana perubahan yang diinginkan oleh kebijakan

4. Apakah letakan sebuah program sudah tepat

5. Siapa pelaksana program

6. Apakah sebuah program didukung oleh sumber daya yang memadai Sedangkan variable lingkungan kebijakan mencakup hal-hal sebagai berikut:

1. Seberapa besar kekuasaan, kepentingan dan strategi actor yang terlibat

2. Karakteristik institusi dan rezim yang sedang penguasa

3. Kepatuhan dan daya tanggap

Dari isi kebijakan konteks tersebut Grindle dalam nawawi dijelaskan:

1. Interest affected (kepentingankepentingan yang mempengaruhi) Berkaitan dengan berbagai pelaksanaannya pasti melibatkan banyak kepentingan dan sejauh mana kepentingan tersebut membawa pengaruh terhadap implementasinya

2. Type of Benefit ( tipe manfaat) 
Isi kebijakan berupaya untuk menjelaskan bahwa dalam suatu kebijakan harus terdapat jenis manfaat yang menunjukan dampak positif yang dihasilkan oleh pengimplemantasian kebijakan yang hendak dilaksanakan

3. Extent of Change Envision ( derajat perubahan yang ingin dicapai)

Setiap kebijakan mempunyai target yang hendak ingin dicapai, isi kebijakan menjelaskan pada point ini adalah seberapa besar perubahan yang ingin dicapai melalui suatu implementasi kebijakan dalam skala yang sangat jelas

4. Sile of Dicision making (letak pengambilan keputusan)

Pengambilan keputusan dalam suatu kebijakan memegang peranan penting dalam pelaksanaan suatu kebijakan, maka pada bagian ini harus dijelaskan letak pengambilan keputusan dari suatu kebijakan yang akan di implementasikan

5. Program Implementer (pelaksanaan program)

Dalam menjalankan suatu kebijakan atau program harus didukung dengan adanya pelaksana kebijakan yang kompeten dan kapabel demi keberhasilan

6. Resources Commited (sumberdaya yang harus digunakan)

Dalam menjalankan suatu kebijakan juga harus didukung oleh sumberdaya-sumberdaya yang mendukung agar pelaksanaannya berjalan baik
Sedangkan lingkungan kebijakan menurut Grindle mencakup :

1. Power, interest, and strategis of actor involved (kekuasaan, kepentingan, dan strategi dari actoraktor terlibat). Dalam suatu kebijakan perlu diperhitungakan pula kekuatan dan kekuasaan kepentingan serta strategi yang digunakan oleh para actor yang terlibat guna memperlancarkan jalannya pelaksanaan suatu implementasi kebijakan. Bila hal ini tidak diperhitungkan dengan matang maka sangat besar kemungkinan program yang hendak dijalankan berhasil

2. Institution and Regine Characteristic (karakteristik lembaga dan rezim berkuasa). Lingkungan dimana suatu kebijakan tersebut dilaksanakan juga berpengaruh terhadap keberhasilan, maka pada bagian karakteristik dari suatu lembaga yang akan turut mempengaruhi suatu kebijakan

Compliance and Responsiveness (pemenuhan dan daya tanggap). Hal ini yang dirasakan penting dalam proses pelaksanaan adalah kepatuhan dan respon dari para pelaksana, maka yang hendak dijelaskan pada point ini adalah sejauh mana kepatuhan dan respon dari pelaksana dalam menanggapi suatu kebijakan

\section{METODE PENELITIAN}

Dalam penelitian ini, peneliti menggunakan pendekatan kualitatif. Penelitian kualitatif dimaksudkan sebagai jenis penelitian yang temuan-temuannya 
NAKHODA:

JURNAL

ILMU PEMERINTAHAN
NAKHODA: JURNAL ILMU PEMERINTAHAN

Edisi Januari - Juni 2019 Volume: 18 Nomor: 31

ISSN : 1829-5827 |E-ISSN : 2656-5277

DOI : https://doi.org/10.35967/jipn

https://nakhoda.ejournal.unri.ac.id/index.php/JIPN tidak diperoleh melalui prosedur statistik atau bentuk hitungan lainnya.(Ansem strauss \& Juliet Corbin,2013) Menurut Jhon SW. Creswell mendefenisikan pendekatan kualitatif sebagai sebuah proses penyelidikan untuk memahami masalah sosial atau masalah manusia berdasarkan pada penciptaan gambar holistik yang dibentuk dengan kata-kata, melaporkan pandangan informan secara terperinci, dan disusun dalam sebuah latar ilmiah.(Hamid Patiliam,2011) Dalam pendekatan kualitatif data yang dikumpulkan adalah data dalam bentuk narasi dan angka-angka (sensus, misalnya). Data dianalisis untuk dijadikan bukti-bukti yang perlu diinterprestasi untuk mendukung kebenaran dari hipotesa/proposisi yang digunakan dalam penelitian.

Dalam penelitian ini, peneliti menggunakan pendekatan kualitatif. Penelitian kualitatif dimaksudkan sebagai jenis penelitian yang temuan-temuannya tidak diperoleh melalui prosedur statistik atau bentuk hitungan lainnya.(Ansem strauss \& Juliet Corbin,2013) Menurut Jhon SW. Creswell mendefenisikan pendekatan kualitatif sebagai sebuah proses penyelidikan untuk memahami masalah sosial atau masalah manusia berdasarkan pada penciptaan gambar holistik yang dibentuk dengan kata-kata, melaporkan pandangan informan secara terperinci, dan disusun dalam sebuah latar ilmiah.(Hamid Patiliam,2011) Dalam pendekatan kualitatif data yang dikumpulkan adalah data dalam bentuk narasi dan angka-angka (sensus, misalnya). Data dianalisis untuk dijadikan bukti-bukti yang perlu diinterprestasi untuk mendukung kebenaran dari hipotesa/proposisi yang digunakan dalam penelitian. Teknik pengumpulan data dokumentasi, wawancara dan observasi.

\section{HASIL DAN PEMBAHASAN}

Faktor-faktor yang mempengaruhi Pelaksanaan Pembangunan Desa

\section{Isi Kebijakan}

a. Kepentingan-kepentingan yang mempengaruhi

Pembangunan di desa sei putih melibatkan banyak aktor-aktor yang mempengaruhi mulai dari perangkat desa, lembaga swadaya masyarakat, masyarakat. Alokasi terhadap anggaran yang akan digunakan tentunya harus dilakukan bersama dengan masyarakat dan di dukung oleh LKMD Desa Sei Putih sebagai mitra kerja untuk ikut membantu di dalam pembangunan Desa Sei Putih. Dari mulai penyusunan rencana pembangunan, menyampaikan aspirasi dari pembangunan tersebut dan ikut serta dalam pembangunan itu sendiri. Namun actor yang terlibat seperti LKMD desa sei putih kurangnya tanggung jawab LKMD dalam melaksanakan-melaksanakan tugasnya. Serta kurangnya kreatifitas juga menjadi penghambat kurang optimalnya pembangunan yang ada di Desa. Hali ini dikarenakan Ketua LKMD Desa Sei putih juga memiliki kesibukan di luar kota. LKMD Desa Sei Putih jarang berada di Desa karena memiliki usaha yang ada di luar Kota, dan jarang mengikuti rapat rapat yang di adakan di Desa. Jika ketua LKMD nya tidak aktif dalam pembangunan di Desa, tentu hal ini tidak bisa menggerakkan masyarakat untuk berkontriusi dalam pembangunan di desa. Perbedaan kepentingan dari pemerintah 
NAKHODA:

JURNAL

ILMU PEMERINTAHAN
NAKHODA: JURNAL ILMU PEMERINTAHAN

Edisi Januari - Juni 2019 Volume: 18 Nomor: 31

ISSN : 1829-5827 |E-ISSN : 2656-5277

DOI : https://doi.org/10.35967/jipn desa dan lembaga swadaya masyarakat (LKMD) dalam membangun desa menjadi factor yang menghambat dalam pembangunan di desa sei putih.

\section{b. Manfaat yang akan dihasilkan}

Pembangunan di desa sei putih melakukan pembangunan dengan menyusun rencana pembangunan melalui musrenbang desa dengan mengundang lembaga swadaya masyarakat dan actor-aktor lainnya untuk memberikan masukan terhadap pembangunan. Pembangunan infrastruktur yang akan dilakukan untuk memberikan masyarakat akan manfaat untuk Peningkatn Akhlak dan Moral melalui pembangunan gedung TPA dan masjid agar memberikan kemudahan masyarakat untuk beribadah, Meningkatkan ekonomi rakyat melalui pembangunan pasar dan rumah layak huni karena itu merupakan tugas pemerintah untuk memberikan pelayanan dan pembangunan, Meningkatkan sumber daya manusia melalui pendidikan anakanak usia dini untuk mengembangkan minat bakat dengan pembinaan dan pelatihan, Meningkatkan pelayanan kesehatan agar bisa memberikan puskesmas pembantu di desa-desa agar kesehatan masyarakat terjaga dan memudahkan masyarakat ingin berobat dan Meningkatkan infrastruktur jalan agar akses masyarakat desa berjalan dengan baik.

\section{c. Derajat perubahan yang ingin dicapai}

Pembangunan dilakukan tentu ini memberikan derajat perubahan yang lebih baik. Namun dalam realisasi tidak semua yang telah direncanakan bisa lakukan. realisasi pembangunan di Desa Sei Putih Kecamatan Tapung Kabupaten Kampar. Pelaksanaan pembangunan di Desa dalam pembangunan gedung TPA yang terealisasi hanya Rp. 58.000.000 atau $40 \%$, Pembangunan gedung MDA nurul iman tidak terealisasi sama sekali atau 0\%, Pembangunan Masjid dan Mushalla yang terealisasi hanya Rp. 93.750 .000 atau $75 \%$, pembangunan los pasar Desa sudah terealisasi 100\%,Bantuan Ternak Sapi tidak terealisasi sama sekali atau 0\%, Rumah Layak Huni tidak terealisasi sama sekali atau 0\%, Pembangunan Gedung Paud yang terealisasi hanya Rp. 256.000 .000 atau $100 \%$, Pembangunan Gedung Sma yang terealisasi hanya Rp. 224.624.000 atau 55,6\%, Pembangunan Gedung Puskesdes Pembantu yang terealisasi hanya Rp. 96.000.000 atau 64\%, Pengaspalan Jalan Poros Teratai 1,6 Dan 7 yang terealisasi hanya Rp. 797.500.000 atau $58 \%$, Pengerasan Jalan Lingkungan Desa Teratai 2,3 Dan 5 yang terealisasi sudah sebesar Rp. 1.666.000.000 atau 98\%, Pembangunan Pagar Kantor Desa sudah terealisasi mencapai $100 \%$, Pembangunan Gapura Desa yang terealisasi hanya Rp. 367.000.000 atau $34 \%$.

\section{d. Letak pengambilan keputusan}

Pelaksanaan pembangunan desa, banyak pihak yang berperan dalam penyelenggraannya termasuk peran dari kepala desa dan aparat 
pemerintah desa. Kepala desa merupakan ujung tombak dari pembangunan, peran seorang kepala desa sangat besar pengaruhnya. Hal ini disebabkan karena kepala desa adalah pemegang kekuasaan tertinggi di desa. Yang dapat membuat keputusan, membimbing, membina, mengarahkan, menampung aspirasi masyarakat, serta mempengaruhi anggota masyarakatnya untuk bekerjasama dalam dalam mencapai tujuan dari pembangunan itu sendiri.Pengambilan keputusan terletak kepada pemerintah desa yakni kepala desa bersama perangkat desa yang sebelumnya telah disetujui bersama masyarakat dan BPD terhadap pembangunan di desa sei putih. Namun masih rendahnya kemampuan pemerintah desa dalam hal ini kepala desa dalam mengelola pembangunan dan memberikan skala prioritas terhadap pembangunan yang akan dilakukan sehingga pembangunan yang dilakukan tidak optimal sepenuhnya sehingga terjadi penundaan-penundaan pembangunan yang dilakukan seperti rumah layak huni, pembangunan gedung sekolah, pembangunan pustu. Tentu sebagai pemimpin pemerintahan desa, kepala desa harus mampu meyakinkan masyarakat dan lembaga swadaya masyarakat dalam memberikan kontribusi untuk pembangunan desa.

\section{e. Pelaksana program}

Kurangnya pengawasan

pemerintah di desa Sei Putih Kecamatan Tapung Kabupaten Kampar, sehingga kurang efektif dan efisien pekerjaan yang dilakukan dan minimnya tenaga di lapangan. Pelaksana pembangunan dilakukan masyarakat desa namun orang-orang yang mengerjakan merupakan orang dekat dari perangkat pemerintahan desa sehingga pengawasan terhadap pembangunan tidak dilakukan hal ini terlihat dalam Pembangunan Masjid dan Mushalla bantuan dari desa pembuatannya sangat memakan waktu yang lama. Dan para pekerja tidak bekerja dengan sungguh-sungguh. Tentu pemilihan pelaksana program pembangunan di desa haruslah orangorang yang professional dan memiliki target penyelesaian sesuai kesepakatan yang telah ditentukan. Berkaitan dengan pemilihan actor pelaksana mempengaruhi dalam menghambat proses pembangunan dalam pembangunan di desa sei putih.

\section{f. Sumberdaya yang digunakan}

Dalam pembangunan di desa sei putih sangat penting penggunaan sumber daua dengan baik karena faktor ini penting untuk menentukan berhasil atau tidaknya suatu pelaksanaan pembangunan. Meskipun dana yang ada telah mencukupi. Namun jika tidak pandai mengelola maka hasilnya tentu tidak akan optimal. Di Desa Sei Putih, terbatasnya sumber daya manusia berlatar belakang pendidikan yang dibutuhkan di Desa Sei putih membuat terhambat nya proses pembangunan. Pelaksanaan pembangunan di desa Sei putih dirasakan masih belum maksimal. Belum maksimalnya peran kepala desa karena adanya faktorfaktor penghambat, diantaranya : kurangnya pemahaman kepala desa 
NAKHODA:

JURNAL

ILMU PEMERINTAHAN
NAKHODA: JURNAL ILMU PEMERINTAHAN

Edisi Januari - Juni 2019 Volume: 18 Nomor: 31

ISSN : 1829-5827 |E-ISSN : 2656-5277

DOI : https://doi.org/10.35967/jipn

https://nakhoda.ejournal.unri.ac.id/index.php/JIPN dalam pembangunan, Masih rendahnya SDM, kepala desa maupun aparat desa serta masyarakatnya. Dimana sebagian besar masyarakat desa hanya lulusan SD, dan SLTP atau SLTA begitu juga aparat desa yang hanya lulusan SLTA.

\section{Lingkungan Kebijakan}

a. Kekuasaan, Kepentingan, Dan Strategi Dari Actor-Aktor Terlibat

Dalam pembangunan di desa pasti banyak actor yang terlibat dengan kepentingan yang berbeda-beda namun kepentingan yang utama berkaitan dengan pemanfaatan sumber daya anggaran agar bisa dimanfaatkan oleh kekerabatan makanya dalam pelaksanaan program di minta anggota kekerabatan dalam melakukan pembangunan. Kepentingan lain dalam

\section{c. Kepatuhan dan Daya Tanggap \\ Kepatuhan dan daya tanggap} masyarakat dalam pembangunan menjadi tolak ukur untuk memberikan masukan dan dukungan untuk melakukan pembangunan di desa sei putih. Masyarakat masih kurang peduli dalam ikut kegiatan desa berkaitan dengan musrenbang dan pengawasan terhadap pembangunan desa. Hal ini dilihat dari undangan untuk menghadiri musrenbang desa sangat sedikit warga yang datang, dan tidak memberikan ideide atau pendapat tentang kemajuan dan pembangunan di Desa. Sehingga factor eksternal dari masyarakat mempengaruhi dalam pembangunan di desa sei putih.

\section{KESIMPULAN}

Kesimpulan peneliti dalam pembangunan dari actor pemerintah desa dan lembaga swadaya masyarakat tidak saling memberikan masukan dan ketegasan dalam arah pembanguna infrastruktur.

\section{b. Karakteristik Lembaga Dan Rezim Berkuasa}

Karakter rezim dalam hal ini pimpinan masih belum optimal, hal ini dilihat dari pelaksana program yang dilakukan berdasarkan kedekatan kekeluargaan sehingga melaksanakan pembanguna tidak optimal karena tidak ada yang melakukan pengawasan baik dari pemerintah desa, BPD dan masyarakat. Tentunya untuk melakukan pembangunan harus diperbaiki terlebih dahulu lingkungan politik pimpinan atau kepala desa.

peneltian ini berkaitan dengan pembanguna di desa sei baru kecamatan tapung dilihat dari factor-faktor penghambat dalam pelaksanaan melibatkan isi kebijakan dalam hal pembuat kebijakan yang masih belum kompetensi dibidangnya dan pengaruh actor-aktor kepentingan yang mencari keuntungan dalam realisasi pembangunan sehingga hasil pembangunan tidak efektif dan gedung yang sudah dibuat belum bisa digunakan. Sedangkan berkaitan dengan lingkungan kebijakan kepatuhan dan daya tanggap yang masih belum berkontribusi untuk melakukan pembanguna di desa sei putih kecamatan tapung dalam memberikan gagasan pembangunan dan dalam pengawasa terhadap pembangunan. 


\section{NAKHODA:}

JURNAL

ILMU PEMERINTAHAN
NAKHODA: JURNAL ILMU PEMERINTAHAN

Edisi Januari - Juni 2019 Volume: 18 Nomor: 31

ISSN : 1829-5827 |E-ISSN : 2656-5277

DOI : https://doi.org/10.35967/jipn

https://nakhoda.ejournal.unri.ac.id/index.php/JIPN

\section{DAFTAR PUSTAKA}

Mulia, R. A., \& Saputra, N. (2019).

Kontribusi Kompensasi Dan

Motivasi Kerja Terhadap

Kepuasan Kerja Pegawai Di

Dinas Pendidikan Dan

Kebudayaan Kabupaten Agam.

Mulia, R. A. (2019). Analisis Faktor-

Faktor Yang Mempengaruhi

Kualitas Laporan Keuangan

Pemerintah Daerah (Studi Pada

Pemerintah Kabupaten Pasaman

Barat). Jurnal EL-RIYASAH,

9(1), 7-21.

Nugroho, Riant, 2004. Kebijakan Publik

Formulasi, Implementasi, dan

Evaluasi. Jakarta :PT. Gramedia

Patiliman, Hamid, 2011. Metode

Penelitian Kualitatif. Bandung :

Alfabeta
Putri, R. P. (2018). Pemeriksaan

Penggabungan Gugatan Ganti

Kerugian Dalam Perkara Pidana

Di Pengadilan Negeri Kelas 1B

Bukittinggi. Soumatera Law

Review, 1(1), 176-197.

Sujianto, 2009. Pemberdayaan Menuju Masyarakat Mandiri. Pekanbaru :

Alfa Riau

, 2008. Implementasi Kebijakan Publik Konsep dan Praktek. Pekanbaru : Alfa Riau

Strauss, Anselm \& Corbin Juliet. 2003.

Dasar- Dasar Penelitian

Kualitatif. Yogyakarta: Pustaka Pelajar

Winarno, Budi . 2012. Kebijakan Publik, Teori, Proses dan Studi Kasus. Yogyakarta: CAPS 